\title{
Molecular detection of plaice remains in the stomachs of potential predators on a flatfish nursery ground
}

\author{
Aitor Albaina ${ }^{1,3, *}$, Martin I. Taylor ${ }^{1}$, Clive J. Fox ${ }^{2}$ \\ ${ }^{1}$ Molecular Ecology and Fisheries Genetics Laboratory, School of Biological Sciences, ECW Building, Bangor University, \\ Bangor LL57 2UW, UK \\ ${ }^{2}$ Scottish Association for Marine Science, Scottish Marine Institute, Oban, Argyll PA37 1QA, UK \\ ${ }^{3}$ Present address: Laboratory of Genetics, Department of Genetics, Physical Anthropology \& Animal Physiology, \\ University of the Basque Country, Leioa 48940, Spain
}

\begin{abstract}
Stomach contents of potential predators from a flatfish nursery ground on the Scottish west coast were examined visually and probed using a TaqMan real-time PCR based assay designed to detect plaice Pleuronectes platessa DNA. Stomachs from 1137 brown shrimp Crangon crangon, along with a lesser number of shore crab Carcinus maenas, grey gurnard Eutrigla gurnardus and Gobiidae were analysed. Overall $45 \%$ of shrimp tested positive for plaice DNA, a proportion considerably higher than in stomachs containing visually identifiable flatfish remains. When scaled to the population level, predation by shrimp generated an estimated mortality of $\sim 9 \% \mathrm{~d}^{-1}$, which compares with a decline in plaice abundance from mid-May to mid-June of $\sim 4.4 \%$ $\mathrm{d}^{-1}$. The discrepancy between mortality estimates based on molecular and catch-curve analysis might be due to sampling being conducted at low water between dusk and dawn, which would concentrate predators and prey at times coincident with peaks of shrimp feeding. In addition, the sensitivity of the TaqMan assay could have led to some over-estimation because non-fatal interactions may also have been detected, e.g. shrimp are known to nibble the fins of flatfish, that might result in a positive TaqMan result but not necessarily in mortality for the fish. The percentage of shrimp testing positive for presence of plaice DNA in their stomachs was also related to plaice density in a positive, linear manner. For less abundant predators, stomachs of $6 \%$ of shore crabs, $40 \%$ of gurnards and $11 \%$ of large gobies also tested positive.
\end{abstract}

KEY WORDS: Stomach contents · TaqMan real-time PCR assay $\cdot$ Pleuronectes platessa $\cdot$ Crangon crangon $\cdot$ Carcinus maenas $\cdot$ Predator-prey interactions $\cdot$ Nursery ground $\cdot$ Tralee Beach

Resale or republication not permitted without written consent of the publisher

\section{INTRODUCTION}

Although year-class strength in plaice Pleuronectes platessa is thought to be largely determined during the planktonic stages (Bannister et al. 1974, Beverton \& Iles 1992, Ellis \& Nash 1997, van der Veer et al. 2009), post-settlement processes also play an important role in fine-tuning eventual recruitment success (Iles \& Beverton 2000, Nash \& Geffen 2000). Predation by brown shrimp Crangon crangon is thought to be a particularly important source of mortality on recently settled plaice (van der Veer \& Bergman 1987, Burrows et al. 2001, Amara \& Paul 2003). As the fish grow they become less vulnerable to shrimp predation (Gibson et al. 1995), and as an implication, shore crabs Carcinus maenas (van der Veer \& Bergman 1987, Amara \& Paul 2003), other fish (Ellis \& Gibson 1995, Gibson \& Robb 1996) and birds (Leopold et al. 1998) are thought to become increasingly important sources of mortality. 
Most studies on predation of fish have been based on visual identification of prey remains in predator stomachs, but identifying partially digested prey can be difficult (Gibson \& Robb 1996, Ansell et al. 1999). Oh et al. (2001), for example, grouped all fish remains together whilst Gibson \& Robb (1996) and Ansell et al. (1999) were unable to identify juvenile flatfish remains below family level. Bony parts, such as fin-rays and otoliths, are more resistant to digestion and can often be recovered from the stomachs of predators, and this method has been widely applied to diet studies of marine mammals (Labansen et al. 2007) and seabirds (Hamer et al. 2007). Otoliths from older fish can often be identified to species on the basis of their unique shapes (Granadeiro \& Silva 2000), but assigning otoliths from very young fish to the species level is usually impossible. For example, van der Veer \& Bergman (1987) assigned fin-rays and otoliths in shrimp and crab stomachs as plaice, but only because there were no other juvenile flatfish species present in the area. At other locations, such as Tralee Beach on the Scottish west coast, juvenile plaice, flounder and dab co-occur (Gibson et al. 1996). Although there is some differentiation in timing of settlement and depth preference between these species (Burrows et al. 1994), overlap in the diets of predators is likely.

Modern molecular methods offer an alternative approach to the identification of prey remains that is potentially more rapid and species specific than visual identification (Symondson 2002, King et al. 2008). Several molecular studies of predator stomach contents have employed immunoassays (Bailey et al. 1993, Taylor 2004, 2005a,b) but these are expensive to develop so most studies have used DNA-based methods. Using standard PCR, Asahida et al. (1997) were able to detect stone flounder Kareius bicoloratus DNA in shrimp Crangon affinis stomachs, whilst Saitoh et al. (2003) studied the range of predators consuming hatchery-reared Japanese flounder Paralichthys olivaceus in the wild. Positive results were obtained from a range of organisms including a cephalopod Sepioteuthis lessoniana not previously recognised as a predator on juvenile flounder. Other applications of molecular methods to study marine diets include work on copepods (Nejstgaard et al. 2003), appendicularians (Troedsson et al. 2007), squid (Braley et al. 2010), fish (Rosel \& Kocher 2002, Smith et al. 2005, Barnett et al. 2010) and seals (Deagle et al. 2009, Marshall et al. 2010).

The aims of the present study were to use a newly developed TaqMan real-time Polymerase Chain Reaction (PCR) based assay to evaluate the levels of predation experienced by recently settled plaice at Tralee Beach. Although the range of predators capable of taking post-settlement flatfish at this site is well known (Gibson et al. 1993, 1998, Gibson \& Robb 1996, Ansell et al. 1999), there remains considerable uncertainty about the total impacts of different predators on the flatfish (Burrows et al. 2001). The study also compared results from the molecular analysis with those from previous studies based on visual stomach-content analysis.

\section{MATERIALS AND METHODS}

\section{Study area and sample collection}

Tralee Beach is situated in Ardmucknish Bay on the west coast of Scotland $\left(56.48^{\circ} \mathrm{N}, 5.42^{\circ} \mathrm{W}\right)$. The beach is well known as a flatfish nursery and has provided the location for several ecological studies (e.g. Gibson et al. 1993, 1996, 2002, Burrows et al. 1994, Gibson \& Robb 1996, Ansell et al. 1999).

Pilot sampling was undertaken during spring 2008 (data not shown) and confirmed that stomach fullness of brown shrimp tended to peak shortly after dusk and dawn and stomach fullness of shore crabs peaked around midnight, in accordance with previous literature reports (Pihl \& Rosenberg 1984, Ansell \& Gibson 1993, del Norte-Campos \& Temming 1994, Ansell et al. 1999). Since brown shrimp are thought to be the main source of predation on recently settled plaice, the main sampling program was designed with regard to this predator. Samples in 2009 were collected at low water in depths $<1 \mathrm{~m}$ within $2 \mathrm{~h}$ of dusk, midnight or dawn. Sampling took place approximately every 5 d during May and early June (Table 1). Fishing was conducted using a $1.5 \mathrm{~m}$ beam trawl fitted with a single spiked tickler chain and a double net (outer net $10 \mathrm{~mm}$ stretched diamond mesh; inner $4 \mathrm{~mm}$ circular mesh). The trawl was towed manually

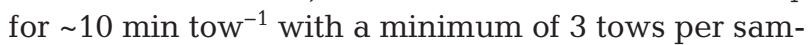
pling date. Tow distances were recorded using a Garmin GPS and swept areas $\left(\mathrm{m}^{2}\right)$ estimated as tow distances multiplied by $1.5 \mathrm{~m}$.

Catches from the beam trawl were immediately pre-sorted on the beach into juvenile flatfish and potential predators (mainly shrimp and crabs but also some roundfish). Juvenile flatfish were preserved in $100 \%$ ethanol because the samples were also to be used for otolith microincrement analyses, and potential predators were wrapped in foil and flash-frozen using a liquid nitrogen dry-shipper for transfer to the laboratory. 
Table 1. Survey details for plaice and potential predators sampling during spring 2009 at Tralee Beach (Ardmucknish Bay, west Scotland). Samples were collected with a $1.5 \mathrm{~m}$ beam trawl approximately every $5 \mathrm{~d}$ at low water in depths $<1 \mathrm{~m}$ within $2 \mathrm{~h}$ of dusk, midnight or dawn. Trawls were towed for $\sim 10$ min tow $^{-1}$ with a minimum of 3 tows per sampling date and swept areas $\left(\mathrm{m}^{2}\right)$ estimated as tow distances multiplied by the trawl diameter

\begin{tabular}{|lcccc|}
\hline $\begin{array}{l}\text { Sampling } \\
\text { date }\end{array}$ & $\begin{array}{c}\text { Day of } \\
\text { year }\end{array}$ & $\begin{array}{c}\text { Time of } \\
\text { day }\end{array}$ & $\begin{array}{c}\text { Water tempe- } \\
\text { rature }\left({ }^{\circ} \mathrm{C}\right)\end{array}$ & $\begin{array}{c}\text { Swept } \\
\text { area }\left(\mathrm{m}^{2}\right)\end{array}$ \\
\hline 25 April & 115 & Midnight & 8.6 & 714.0 \\
01 May & 121 & Dawn & 7.9 & 558.0 \\
04 May & 124 & Dusk & 9.1 & 492.0 \\
09 May & 129 & Midnight & 8.5 & 514.5 \\
16 May & 136 & Dawn & 8.6 & 480.0 \\
21 May & 141 & Dusk & 10.6 & 502.5 \\
25 May & 145 & Midnight & 9.4 & 390.0 \\
30 May & 150 & Dawn & 11.5 & 525.0 \\
04 June & 155 & Dusk & 9.8 & 496.5 \\
09 June & 160 & Midnight & 10.1 & 375.0 \\
15 June & 166 & Dawn & 11.0 & 400.5 \\
\hline \multicolumn{5}{|c}{} \\
\hline
\end{tabular}

Carcinus maenas were not caught in large numbers in the beam trawl. Occasionally, they were observed to be feeding on juvenile plaice in the net. We therefore collected additional samples of shore crabs using a hand-net and electric torch thus ensuring that crabs and juvenile plaice could not come into contact after capture. Crabs were collected around midnight when they are most active (Burrows et al. 1994, Ansell et al. 1999), but this method of collection was only possible on very calm nights and so was limited to 3 occasions. These animals were used for subsequent molecular testing whilst crabs caught by beam trawl were only used to estimate density.

\section{Identification of predators and prey}

Juvenile flatfish were identified to species by fin-ray count (Nichols 1971) and their total lengths recorded under an Olympus SZX9 stereomicroscope using a graticule slide (Cambridge Graticules). Fish lengths were not corrected for shrinkage. Although length corrections for juvenile plaice fixed in formalin are available in Lockwood \& Daly (1975), there are no published corrections for ethanol preservation.

To minimise post-mortem degradation of gut contents, potential predators were covered with $80 \%$ ethanol and allowed to thaw at room temperature. They were then identified to the lowest practical taxonomic category and measured as cephalothorax length (CL) for shrimps, cephalothorax width (CW) for crabs and total length (TL) for fish.
Trawl catch data were converted to numbers per $1000 \mathrm{~m}^{2}$ of swept area but were not corrected for net avoidance, except in density estimates for plaice and Crangon crangon used later for mortality estimation. Catchability estimates for species other than plaice and C. crangon in small beam-trawls are not available.

\section{Analysis of gut contents of potential plaice predators}

After being measured, shrimp $\geq 7 \mathrm{~mm}$ CL (equivalent to $28.5 \mathrm{~mm}$ TL) were stored individually in tubes containing fresh $80 \%$ ethanol. Van der Veer \& Bergman (1987) reported that shrimps <30 mm TL are unable to predate juvenile flatfish so shrimps smaller than this were excluded from stomach analyses. Crustaceans with softened exoskeletons were also excluded as feeding largely ceases during ecdysis (Oh et al. 2001). Stomachs were dissected out from all beam-trawl caught roundfish that were $\geq 44.5 \mathrm{~mm}$ TL and all hand-net collected crabs and preserved individually in tubes containing fresh $80 \%$ ethanol. All instruments were flame-sterilised between each dissection.

\section{Visual identification of stomach contents}

During stomach dissection the following criteria were scored: sex (only for crustacea); gonad stage (only for female crustacea) as 1 (immature, no ovarian thickening), 2 (thickened ovarian diverticula not reaching the cardiac stomach), 3 (ripe, thickened ovarian diverticula extending over the cardiac stomach), or 4 (ovigerous, individuals carrying eggs); and stomach fullness was assigned as $1(<1 / 10$ of the volume filled), 2 (between 1/10 and half full), or 3 (volume completely filled). Stomach contents were visually examined under the stereomicroscope and any obvious identifiable remains noted; however stomach contents were not sorted microscopically as this could have increased the risk of cross-contamination of DNA.

\section{Detection of plaice DNA within stomach contents}

We used a TaqMan real-time PCR based assay to detect plaice DNA in predator stomachs. This probe is highly species specific and has been tested against 
a wide range of marine organisms with no crossreaction (Albaina et al. 2010). At higher temperatures, digestion proceeds more rapidly and timedetection thresholds are reduced. For organisms showing distinct feeding periods within any $24 \mathrm{~h}$, samples should be collected within, at most, $6 \mathrm{~h}$ of the expected peak of feeding.

Whole shrimp stomachs (due to the relatively small sizes of the shrimps) and stomach contents (from crabs and fish) were partially homogenized in $1.5 \mathrm{ml}$ autoclaved Eppendorf tubes containing either $450 \mathrm{\mu l}$ (Crangon crangon) or $675 \mu l$ (Carcinus maenas and fish) of extraction buffer (30 mM Tris, $10 \mathrm{mM}$ EDTA and $1 \%$ sodium dodecyl sulphate). Then, $10 \mu \mathrm{l}$ of proteinase K (Qiagen) was added and the samples digested overnight at $55^{\circ} \mathrm{C}$. DNA was purified following a modified salt protocol (Aljanabi \& Martinez 1997) using $1.2 \mathrm{ml}$ wells in 96 well blocks (Sarstedt MegaBlock; Crangon crangon) or $1.5 \mathrm{ml}$ Eppendorf tubes (Carcinus maenas or fish). The DNA was resuspended in $100 \mu \mathrm{l}$ ultrapure $\mathrm{H}_{2} \mathrm{O}$ and stored at $-20^{\circ} \mathrm{C}$. An extraction blank control (negative control, where no tissue is added to the extraction buffer prior to DNA extraction protocol) was included every 11 samples to detect cross-contamination. DNA yield (ng $\mathrm{\mu l}^{-1}$ ) and 2 purity indexes, determined from the absorbance (A) at different wavelengths ( $\mathrm{nm}$; A260/ A280 and A260/A230 ratios), were determined using a NanoDrop ND-1000 spectrophotometer. While the yield detection limit is set below $2{\mathrm{ng} \mathrm{l}^{-1}}^{-1}$, a ratio $>1.8$ for both sample absorbance indexes is associated with pure DNA (NanoDrop ND-1000 V3.5 User's Manual).

TaqMan assays were run on an Applied Biosystems 7900 real-time sequence detection system following Albaina et al. (2010). PCR inhibiting compounds are often extracted along with DNA from stomach contents of crustaceans in particular. Albaina et al. (2010) demonstrated that PCR inhibition could be overcome using a combination of the addition of $1.25 \mu \mathrm{g} \mathrm{ul}^{-1}$ bovine serum albumin (BSA) along with a dilution step. Therefore, the TaqMan assays were run using both a non-diluted and 1/10 dilution for Crangon crangon DNA extracts with yields $<100 \mathrm{ng}^{-1} \mathrm{l}^{-1}$ (extracting the whole stomach) and for Carcinus maenas $<10 \mathrm{ng}^{-1} \mathrm{l}^{-1}$ (extracting only the stomach's contents), while the assay was run for a combination of 1/10 and 1/100 dilution for Crangon crangon DNA extracts yielding $>100 \mathrm{ng}^{-1} \mathrm{l}^{-1}$ and for Carcinus maenas yielding $>10 \mathrm{ng} \mathrm{l}^{-1}$. For fish, the same dilutions as Carcinus maenas were applied. Twenty $\mu \mathrm{l}$ volume reactions were run in Optical 96-well reaction plates using Optical Adhesive Covers (Applied Biosystems). Each
$20 \mu \mathrm{l}$ reaction contained $0.48125 \mu \mathrm{l}$ of plaice probe $\left(10 \mu \mathrm{M}_{i}\right.$ VIC reporter), $1.3125 \mu \mathrm{l}$ of the PLA-F and PLA-R primers $\left(10 \mu \mathrm{M}_{i}\right.$ Forward and Reverse PLAice primers), $8.75 \mu \mathrm{l}$ of TaqMan Universal PCR Master Mix (NO UNG + ROX passive reference; Applied Biosystems), $3.45625 \mu \mathrm{l}$ tissue culture $\mathrm{H}_{2} \mathrm{O}$ (Sigma), $2.5 \mu \mathrm{l}$ BSA (\#B9001S New England Biolabs) and $2.1875 \mu \mathrm{l}$ of extracted DNA. Plates were run under real-time conditions on a single dye layer with 2 no template controls (NTCs) and 2 positive controls (DNA extracted from adult plaice muscle tissue) per 96 well plate. The assay was run using 40 PCR cycles with the default cycling conditions; after a first stage of $50^{\circ} \mathrm{C}$ for $2 \mathrm{~min}$ followed by $10 \mathrm{~min}$ at $95^{\circ} \mathrm{C}$, the run included 40 repetitions (cycles) of a $15 \mathrm{~s} 95^{\circ} \mathrm{C}$ stage followed by a $60 \mathrm{~s} 60^{\circ} \mathrm{C}$ one. After PCR, the results were analysed using the Sequence Detection Software version 2.3 (Applied Biosystems). A positive $\Delta \mathrm{Rn}$ threshold (as defined in the rtPCR machine manual) of 0.02 was set for the assay and threshold cycle $\left(C_{\mathrm{t}}\right)$ values were computed; see Albaina et al. (2010) for further details. All amplification curves were checked visually to remove false positive/negative signals. Chi-square tests were computed to examine differences with categorical variables (sex, gonad stage, stomach fullness index and TaqMan assay result).

\section{Plaice mortality estimated by density decline}

Plaice densities were corrected for catchability by beam trawl assuming a fixed catch efficiency of $20 \%$ (Wennhage et al. 1997). Instantaneous mortality for the overall population was then estimated as the linear slope of decline of ln plaice abundance over time from the peak of density (Iles \& Beverton 1991).

\section{Plaice mortality estimated from TaqMan results}

As field digestion rates of the set of potential predators tested for plaice DNA ingestion were not compared, comparisons between species are limited. However, estimates of predation induced mortality based on molecular results were limited to Crangon crangon as this was the only potential predator captured consistently across the study. We made 4 simplifying assumptions: (1) a positive TaqMan assay corresponded to a predation event involving the killing of a single juvenile plaice; (2) C. crangon exhibit a crepuscular feeding pattern and during the period of darkness only 1 plaice consumption event took place per predator yielding a positive TaqMan 
result; (3) any predation event occurring within a $24 \mathrm{~h}$ period would be detected since the TaqMan assay can detect $>90 \%$ of predation events up to $5 \mathrm{~h}$ after ingestion (Albaina et al. 2010); and (4) few if any positive TaqMan results would come from feeding events which took place $>24 \mathrm{~h}$ previously (Albaina et al. 2010). Then

$$
N_{\mathrm{p}}=p \times D_{\mathrm{C}}
$$

where $N_{\mathrm{p}}$ is the mean number of prey consumed over the previous $24 \mathrm{~h}$ per unit area, $p$ is the proportion of positive TaqMan assay results from samples of predators collected in any $24 \mathrm{~h}$ period, and $D_{\mathrm{C}}$ is the estimated density of the predators $(\geq 7 \mathrm{~mm} \mathrm{CL}$ C. crangon) per unit area.

Estimates of prey consumption from sampling undertaken just after dawn should detect nearly all feeding events that occurred between the previous dusk and the sampling (the length of night-time on the Scottish west coast from May onwards is $<7 \mathrm{~h}$ ). Because of the need to sample at low water, this only coincided with dawn for some of the dates. Samples collected around dusk or midnight (Table 1) may have under-estimated total consumption during the previous $24 \mathrm{~h}$ since feeding at the previous dawn would be 15 or more $h$ prior to sample collection. In experiments, detection rates varied between 20 and $50 \%$ after $15 \mathrm{~h}$ post-ingestion depending on sample processing (Albaina et al. 2010). However, because of uncertainties in exactly when animals were feeding we did not attempt to further correct dusk and midnight results.

Both prey and predator densities were corrected for catchability by beam trawl assuming fixed catch efficiencies of $20 \%$ for plaice and $50 \%$ for shrimp (Wennhage et al. 1997). Daily mortality due to shrimp predation was then computed as the fraction of plaice juveniles per unit area eaten by the shrimp:

$$
M_{\mathrm{d}}=\frac{N_{\mathrm{p}}}{\left(D_{\mathrm{P}}+N_{\mathrm{p}}\right)} \times 100
$$

where $M_{\mathrm{d}}$ is the daily percentage mortality on any one sampling date, $N_{\mathrm{p}}$ is the mean number of prey consumed over the previous $24 \mathrm{~h}$ from Eq. (1) and $D_{\mathrm{P}}$ is the estimated density of juvenile plaice per unit area.

\section{RESULTS}

\section{Community composition}

Overall 22 taxa were recorded (Table A1 in the Appendix) with the most common species being brown shrimp Crangon crangon, plaice Pleuronectes platessa, gobies Gobiidae, sandeels Ammodytes spp., shore crab Carcinus maenas, dab Limanda limanda and flounder Platichthys flesus. Small plaice were already present on 25 April at $\sim 0.2$ ind $\mathrm{m}^{-2}$. Plaice densities increased to a peak of 0.86 ind $\mathrm{m}^{-2}$ by mid-May and declined to $\sim 0.2$ ind. $\mathrm{m}^{-2}$ by mid-June (Table 2). Growth increased strongly from mid-May onwards with some individual fish attaining $55 \mathrm{~mm}$ TL by midJune (Fig. 1). However, the size range of the population also increased over time so that at the end of the study fish as small as $15 \mathrm{~mm}$ TL were still being caught. In late April the density of brown shrimp was $\sim 0.2$ ind. $\mathrm{m}^{-2}$ but reached $>2$ ind. $\mathrm{m}^{-2}$ by mid-June (Table 2). The shrimp population consisted of at least 2 cohorts, one present at the start of sampling and one which recruited in early June (Fig. 2). Crab, along with larger gobies and sandeels, did not show clear temporal patterns in size or abundance, although crab densities increased from the start of mid-May and, if considering 0-group category, fish densities did from June (Table 2).

\section{Visual identification of stomach contents}

\section{Shrimp stomach contents}

The stomach contents of 1137 shrimp (CL $\geq 7 \mathrm{~mm}$; non-molting animals) were analysed visually (Table 3). Stomach fullness was significantly different when comparing sampling dates ( $p<0.001$; chisquare test) but not for time of sampling (dusk, midnight and dawn; $p=0.11$ ). There was no clear temporal pattern for shrimps with maximum stomach fullness, which fluctuated between 16 and $76 \%$ of animals examined (mean $45 \%, \mathrm{n}=11$ surveys). However, when stomach fullness data were pooled by sampling time, the incidence of maximum fullness (Index 3; see Methods section) was slightly higher for samples collected at dawn (49\%) compared with midnight $(45 \%)$ or dusk $(40 \%)$, possibly reflecting crepuscular feeding behaviour. Crustacean remains, noted in $28 \%$ of shrimp stomachs, consisted mainly of mysids, amphipods, isopods and juvenile Crangon crangon. Annelids were present in $\sim 4 \%$ of shrimp stomachs whilst fish remains were found in $\sim 2 \%$ of the stomachs. Remains identifiable as flatfish were only found in $0.4 \%$ of stomachs while roundfish remains were slightly more common at $0.7 \%$. Clear temporal changes in prey were only apparent for 


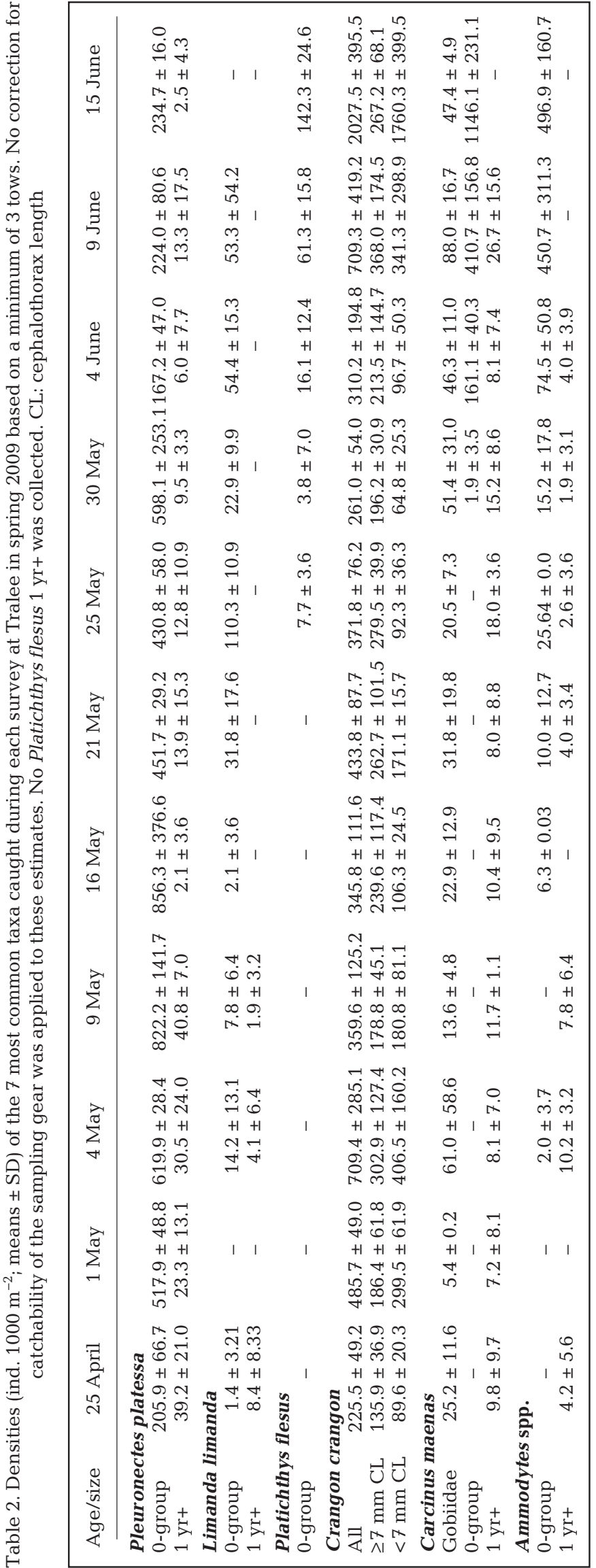

roundfish, which were found in an increasing percentage of stomachs in June (Table 2). Shrimp stomach fullness was significantly affected (chisquare test) by shrimp size $(p<0.001)$, sex ( $p<$ $0.05)$ and gonad stage $(p<0.001)$. Larger shrimp were more likely to be mature females and these animals also tended to have lower gut fullness (Tables 4 \& A2 in the Appendix).

\section{Crab stomach contents}

Only hand-net captured Carcinus maenas, available from 3 dates (25 April, 25 May and 9 June), were used for visual stomach content analysis. These animals $(\mathrm{n}=87)$ had a mean $\mathrm{CW}$ of $48.5 \mathrm{~mm}$ and were $40 \%$ female, of which $22 \%$ were ovigerous or about to spawn. Full stomachs (fullness index 3) were found in $61 \%$ of the crabs overall. Remains of molluscs occurred in $24 \%$ of the dissected stomachs but, apart from 1 stomach containing crustacean remains, there were no other visually identifiable items.

\section{Fish stomach contents}

Four species of fish that could be potential predators of juvenile plaice were caught by beam trawl (Table A3; 1 individual Agonus cataphractus $99.5 \mathrm{~mm}$ TL with an empty stomach was not included). The majority of individuals had full or nearly full stomachs (fullness index 3). The stomachs of sandeels contained mainly unidentified plankton (83\% of individuals) but no fish. Goby stomachs contained mostly unidentified plankton (89\% of individuals) and crustacea (30\% of individuals) but $9 \%$ also contained fish. One goby stomach (out of 57) contained remains identifiable as a flatfish. All gurnard stomachs contained crustacea and 1 (out of 5) contained remains identifiable as a flatfish.

\section{TaqMan analyses}

$$
\begin{gathered}
\text { Quality of the DNA extraction and control } \\
\text { results }
\end{gathered}
$$

The mean DNA yield from Crangon crangon stomachs was $277.9 \mathrm{ng}^{-1}$ with mean purity indices of 1.94 and 1.59 (260/280 and 260/230 indices respectively). For Carcinus maenas, mean 


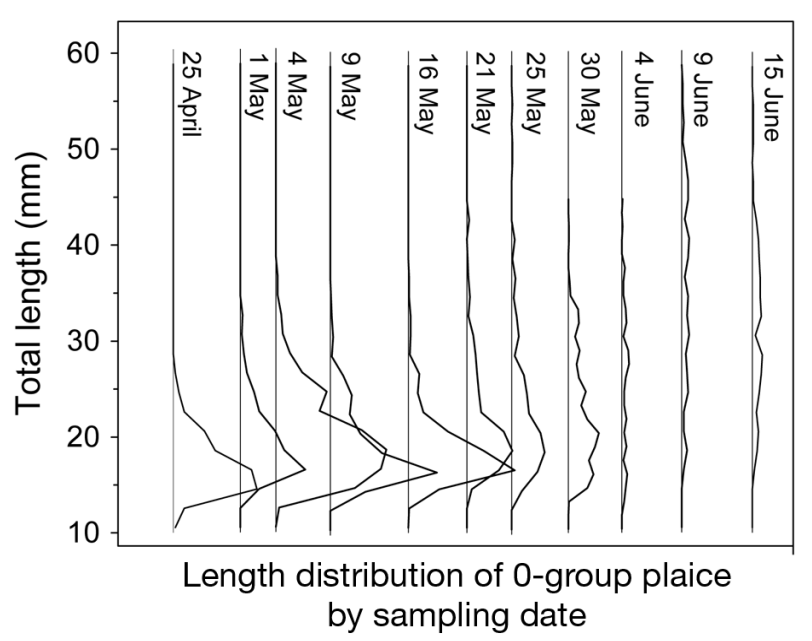

Fig. 1. Pleuronectes platessa. Growth and density of juveniles collected on each sampling date in spring 2009. Length data were binned to $1 \mathrm{~mm}$ categories and the density scaled to unit area (relative units)

yields were $889.8 \mathrm{ng}^{-1} \mathrm{l}^{-1}$ and purity indexes were 1.4 and 0.62 . For the 81 stomach contents analysed from fish, mean DNA yield was $1355.2 \mathrm{ng}^{-1} \mathrm{l}^{-1}$ and purity indexes were 1.98 and $1.80(260 / 280$ and 260/230 indices respectively). All positive controls yielded positive results whilst 1 out of 106 negative controls reacted positively.

\section{TaqMan results from shrimp stomachs}

Overall $45 \%$ of the 1137 Crangon crangon stomachs analysed gave a positive reaction for plaice DNA (Table 5). When pooling individuals by size categories ( 7 to $8.5,9$ to 10.5 and $\geq 11 \mathrm{~mm} \mathrm{CL}$ ), sex or gonad stages, no significant differences were revealed (chi-square test). Differences were significant ( $p<0.001$; chi-square test) comparing both sampling date and time of sampling. The percentage of positive TaqMan responses by sampling date varied between 20 and $91 \%$ (Table 5). There was no strong temporal pattern, although there were relatively fewer positive results later in the study (Fig. 3). Positive detection of plaice DNA in shrimp stomachs increased from $\sim 38 \%$ for both dusk and midnight sample collections to $59 \%$ in samples collected around dawn (Table 5), and these differences were statistically significant $(p<$ 0.001; chi-square test). The proportion of positive TaqMan results from C. crangon stomachs was also positively related with estimated plaice density (Fig. 4).

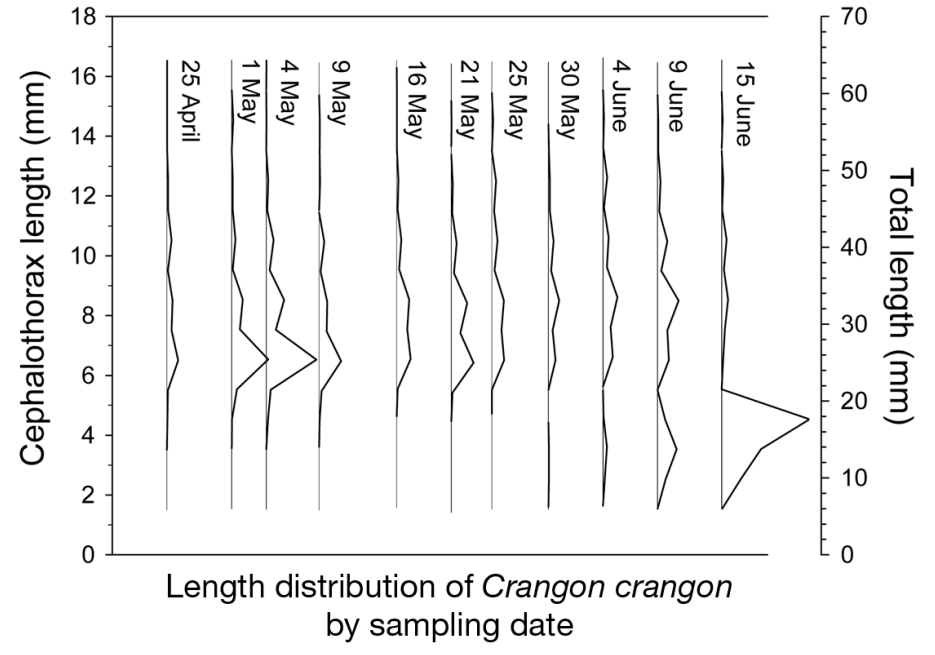

Fig. 2. Crangon crangon. Growth and density of brown shrimp collected on each sampling date in spring 2009. Length data were binned to $1 \mathrm{~mm}$ categories and the density scaled to unit area (relative units). Measurements on a subset of 97 shrimp allowed interconversion of total and carapace lengths as: TL $=4.0124 \times \mathrm{CL}+0.4282\left(\mathrm{R}^{2}=0.99, \mathrm{p}<\right.$ 0.001). TL: total length from the tip of the rostrum to the tip of the telson; CL: cephalothorax length from the tip of the rostrum to the end of the thorax

TaqMan results from crab stomachs

The percentages of Carcinus maenas stomachs testing positive for plaice DNA on each sampling varied from 0 to $12 \%$ (Table 5). The minimum CW for a crab yielding a positive result was $31.5 \mathrm{~mm}$.

\section{TaqMan results from fish}

No sandeel stomachs tested positive for plaice DNA ( $\mathrm{n}=18$ ), but $\sim 11 \%$ of Gobiidae stomachs $(\mathrm{n}=$ 57) yielded positive results (Table 5). For gurnards $40 \%$ gave a positive result, although the sample size was small $(\mathrm{n}=5)$.

Estimation of the predation impact of shrimp on juvenile plaice

Instantaneous population mortality was estimated to be 0.0448 ind. $\mathrm{d}^{-1}$, which corresponded to an absolute mortality rate of $4.4 \%$ ind. $\mathrm{d}^{-1}$ (Fig. 5). The predation impact of shrimp based on the TaqMan results (Fig. 6) was relatively stable across the season and varied between 5 and $20 \% \mathrm{~d}^{-1}$ (corresponding to 0.051 and 0.223 ind. $\mathrm{d}^{-1}$ instantaneous mortality) with higher values in June. 


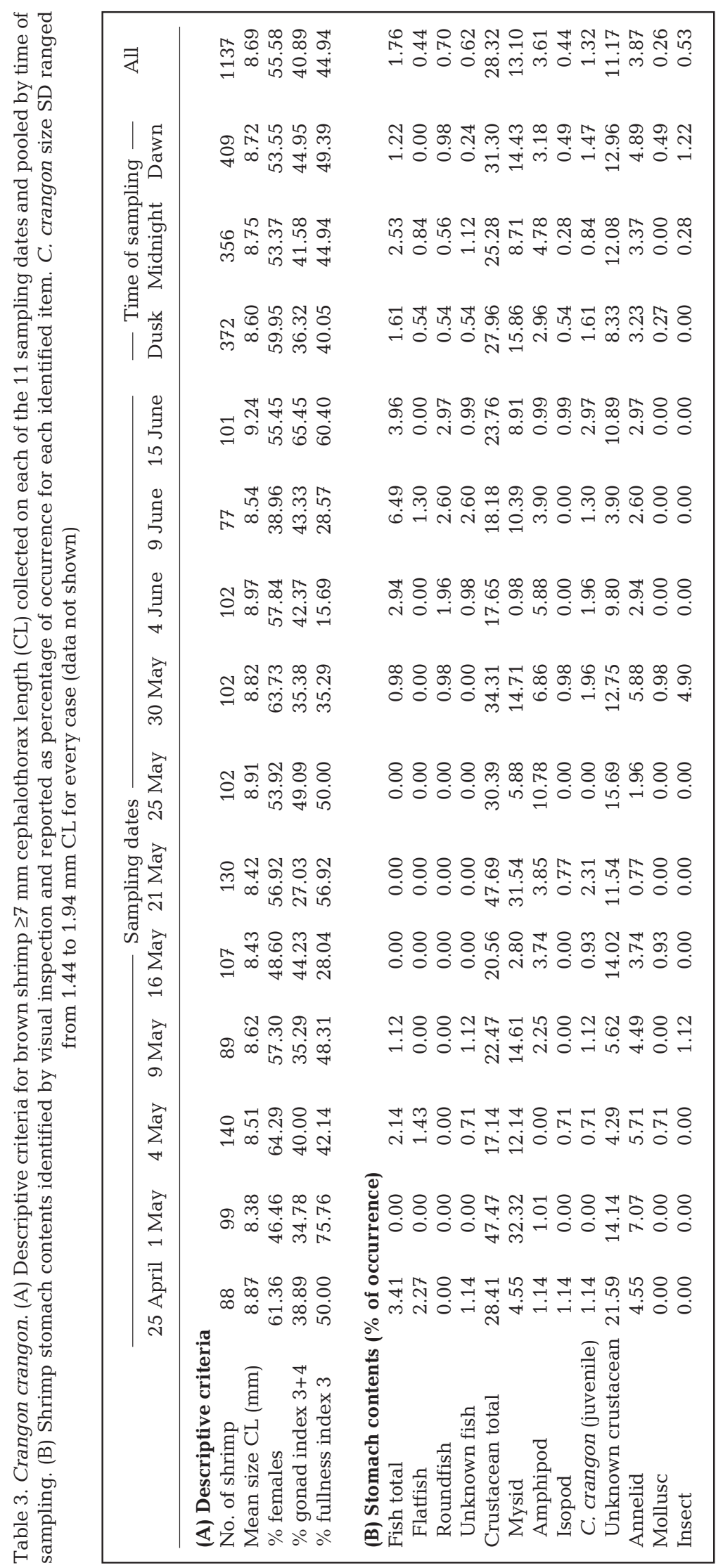

\section{DISCUSSION}

\section{Predation and mortality rates}

Overall $\sim 45 \%$ of brown shrimp stomachs tested positive with the TaqMan assay, suggesting that shrimp do play a major role as predators on recently settled plaice in line with previous reports (van der Veer \& Bergman 1987, Ansell et al. 1999, Burrows et al. 2001, Oh et al. 2001, Amara \& Paul 2003).

Estimated daily mortality due to shrimp based on TaqMan results (Fig. 6) was approximately twice that estimated from catch-curve analysis across most of the season ( 0.095 and 0.0448 ind. $\mathrm{d}^{-1}$ respectively). Although the 2 estimates were of the same order of magnitude, the difference could be generated by a variety of factors including uncertainties in both catch-curve analysis and in the molecular approach. Catch-curve analysis is strongly affected by the accuracy with which target species abundance can be estimated (Burrows et al. 2001). The catch efficiency of small beam trawls is known to be related to multiple factors including gear design and rigging, tow speed, organism type and size, and ground and sea conditions (Rogers \& Lockwood 1989, Kuipers et al. 1992, Wennhage et al. 1997). Most of these factors are difficult to control and researchers have usually applied relatively simple catch corrections, as in the present study. In 2009, the densities of 0 -group plaice at Tralee ranged from 0.21 to 0.86 ind. $\mathrm{m}^{-2}$ (1.1 to 4.3 ind. $\mathrm{m}^{-2}$ corrected for catchability). These values are within the range of previous estimates reported from this site (Burrows et al. 2001, Nash et al. 2007).

For means computed from $n$ multiple transects, precision improves as $(\sqrt{n})^{-1}$. Precision on our ln density estimates for each sampling should therefore be around \pm 0.58 per $1000 \mathrm{~m}^{2}$ or an order of magnitude lower than the ln observed abundance (Iles \& Beverton 1991). Juvenile plaice mortality rates from a variety of nursery grounds have been reported to be between 0.02 and 0.052 ind. $\mathrm{d}^{-1}$ 
Table 4. Crangon crangon. Effect of size on the (A) descriptive criteria for shrimp $\geq 7 \mathrm{~mm}$ cephalothorax length (CL) collected during sampling and (B) occurrence of species in the diet (\%) of brown shrimp based on visual stomach content analyses. Data were pooled from all sampling dates

\begin{tabular}{|c|c|c|c|}
\hline & \multicolumn{3}{|c|}{$\mathrm{CL}(\mathrm{mm})$} \\
\hline & 7 to 8.5 & 9 to 10.5 & $\geq 11$ \\
\hline \multicolumn{4}{|c|}{ (A) Descriptive criteria } \\
\hline No. of shrimp & 708 & 275 & 154 \\
\hline$\%$ females & 32.63 & 89.82 & 100.00 \\
\hline$\%$ gonad index $3+4$ & 12.99 & 46.56 & 73.38 \\
\hline$\%$ fullness index 3 & 47.60 & 44.73 & 33.12 \\
\hline \multicolumn{4}{|c|}{ (B) \% occurrence in diet } \\
\hline Fish total & 0.42 & 3.64 & 4.55 \\
\hline Flatfish & 0.00 & 1.09 & 1.30 \\
\hline Crustacean total & 26.84 & 34.18 & 24.68 \\
\hline Mysid & 12.29 & 15.64 & 12.34 \\
\hline
\end{tabular}

(Iles \& Beverton 1991). Subsequent studies, including the present one, have tended to generate similar values (Burrows et al. 2001), although Freitas et al. (2010) reported a higher mortality rate of 0.062 ind. $\mathrm{d}^{-1}$ from a Norwegian nursery ground. Our catchcurve estimate of 0.0448 ind. $\mathrm{d}^{-1}$ for 2009 thus lies within the reported range of mortality rates from Tralee and other areas. Iles \& Beverton (1991) also reported the standard error of mortality estimates from catch-curve analyses across multiple study sites at between 0.0014 and 0.0299 ind. $\mathrm{d}^{-1}$. These values bracket a standard error of 0.0145 ind. $\mathrm{d}^{-1}$ in the present study.

Regarding the molecular approach, fin-nibbling of juvenile flatfish by shrimp, as well as failed attacks resulting in wounding, have both been reported (van der Veer \& Bergman 1987, Gibson et al. 1995) and this could result in positive TaqMan results but not in fish mortality. Previous laboratory work (Albaina et al. 2010) examined the post-ingestion decay curve for plaice DNA in shrimp stomachs but not the minimum amount of tissue that would need to be ingested to generate a positive TaqMan response. However, since the method is highly sensitive, it may respond to very small quantities of ingested tissue. The second factor that might lead to over-estimation was our sampling approach, which was designed to maximise the probability of detecting predation events. Sampling at low water is commonly used in juvenile flatfish field studies as it concentrates the fish, improving catch rates and thus the precision of abundance estimates (Nash \& Geffen 2000, Burrows et al. 2001, Fox et al. 2006). However, the coincidence of low water with dusk, dawn or midnight would concen- trate predators and prey together at the time when the shrimp are most likely to be feeding (del NorteCampos \& Temming 1994) and would likely result in increased predation (Burrows et al. 2001). Predation mortality estimated over a complete tidal cycle might therefore be lower than that reported in the present study because the concentration of predators and prey would not always coincide with peaks in predator feeding. Finally, Naviaux et al. (2005) were able to extract and sequence DNA from common beach sand. They reported sequences from a wide range of taxa dominated by Protista but including some teleosts. Since sand grains were noted in many Crangon crangon stomachs, some of the positive TaqMan results could have resulted from ingested sand, although that is unlikely.

\section{Size dependent predation by shrimp}

The relationship between attack success and relative sizes of predator and prey has been well researched for Crangon crangon-plaice interactions. Gibson et al. (1995) showed that around half of attacks succeed when the predator is twice the size of the prey. Based on this result, plaice at the start of sampling in 2009 (mean size $16 \mathrm{~mm} \mathrm{TL}$ ) would have been most vulnerable to attack by shrimp $>32 \mathrm{~mm}$ TL. However, at this time only a small proportion of the shrimp were larger than this size (Fig. 2). As modelled by Burrows et al. (2001), overall predation impacts are the result of a growth race between predators and prey. By mid-May 2009 the size of the juvenile plaice at Tralee had not increased substantially (Fig. 1), but a larger proportion of shrimp were $>32 \mathrm{~mm}$ TL. We might therefore expect overall vulnerability to be greatest at this time Indeed the highest proportion of positive TaqMan results from shrimp stomachs was found on 16 May (91\%), although this was shortly followed by one of the lowest observed proportions (25 May, $23 \%$ ). Gibson et al. (1995) also showed that plaice can usually escape attacks by shrimp when their size is larger than three-quarters of the size of the predator. In late May and early June, the largest shrimp at Tralee were between 40 and $50 \mathrm{~mm}$ TL (Fig. 2) so only plaice larger than 30 to $38 \mathrm{~mm}$ would be very likely to escape. This size refuge is in close agreement with the value of $30 \mathrm{~mm}$ quoted by van der Veer \& Bergman (1987). Plaice growth at Tralee in 2009 only accelerated in late May and even at the end of the study $\sim 50 \%$ of the fish were still $<30 \mathrm{~mm}$ TL. According to Burrows et al. (2001), all plaice would not 


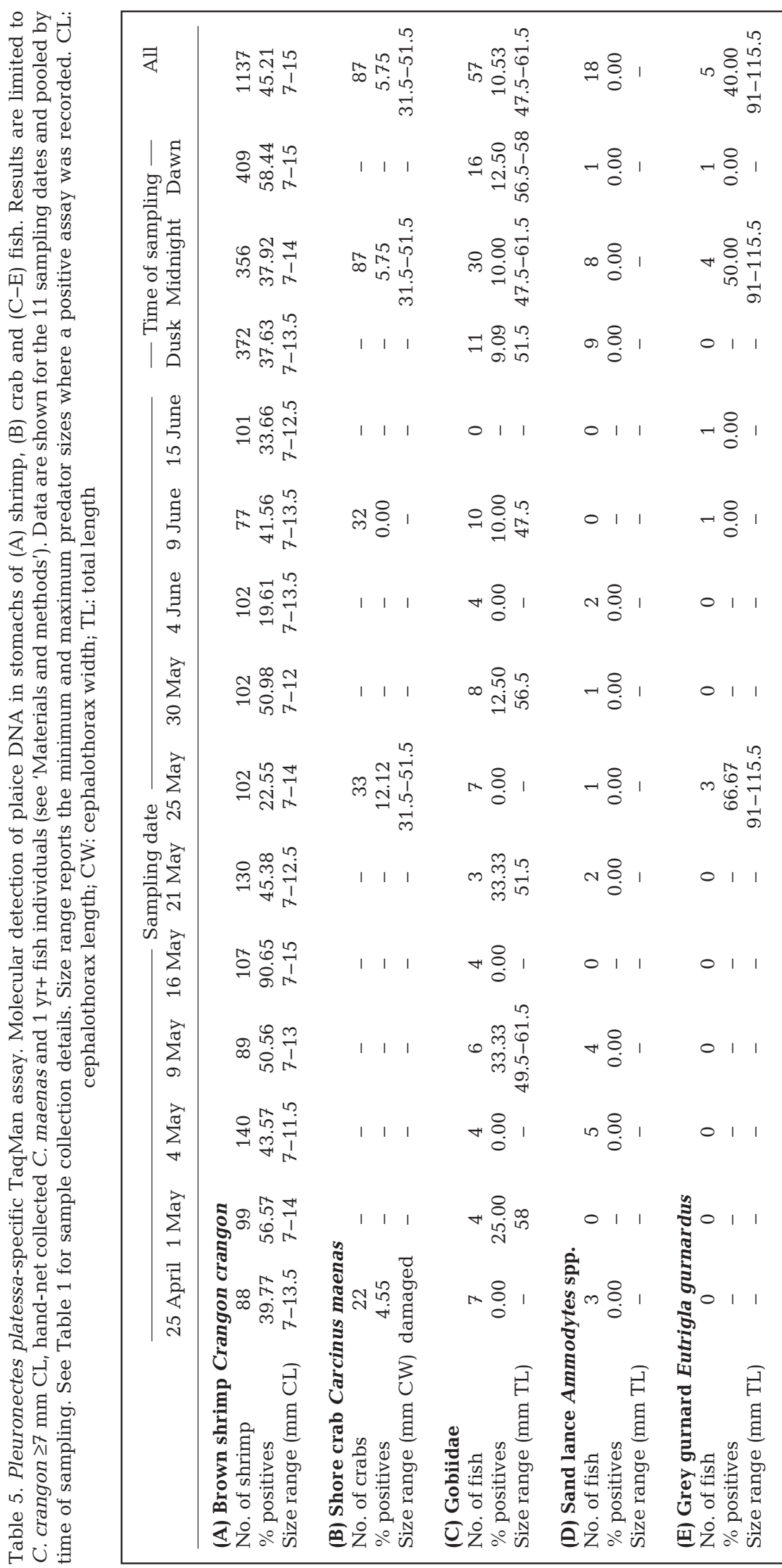

exceed $38 \mathrm{~mm}$ TL until late July or August and thus be safe from shrimp predation. These conclusions are supported by the TaqMan results, which only showed a small decline in positive reactions towards the end of the study (Fig. 3).

The estimated predation impact (Fig. 6) peaked in early June, suggesting that shrimp growth counteracts the overall decline in abundance of plaice of vulnerable size and maintains the rate of shrimp-plaice interactions into early summer. This is again in line with model predictions from Burrows et al. (2001) where predation impact peaked in mid to late May.

\section{Density dependent effects}

Densities of Crangon crangon $\geq 7 \mathrm{~mm}$ CL ( 30 mm TL) at Tralee in 2009 ranged from 0.14 ind. $\mathrm{m}^{-2}$ in late April to 0.37 ind. $\mathrm{m}^{-2}$ by June $(0.28$ to 0.74 ind. $\mathrm{m}^{-2}$ respectively corrected for catchability (Table 2). Again these values lie within the range previously recorded at this site (Burrows et al. 2001).

Overall there was a positive, linear relationship between the proportion of shrimp stomachs containing plaice DNA and plaice density (Fig. 4). This suggests that across the range of shrimp and plaice densities sampled ingestion events were occurring at a constant rate. The effect of availability of alternative prey (e.g. mysids, amphipods, annelids) was not assessed in the present study but should be considered in future work.

\section{Importance of non-shrimp predators}

In addition to shrimp, plaice DNA was detected in stomachs of shore crabs, larger gobies and grey gurnard Eutrigla gurnardus. These results confirm earlier studies where flatfish remains have been found in these predators but specifically confirm the prey 


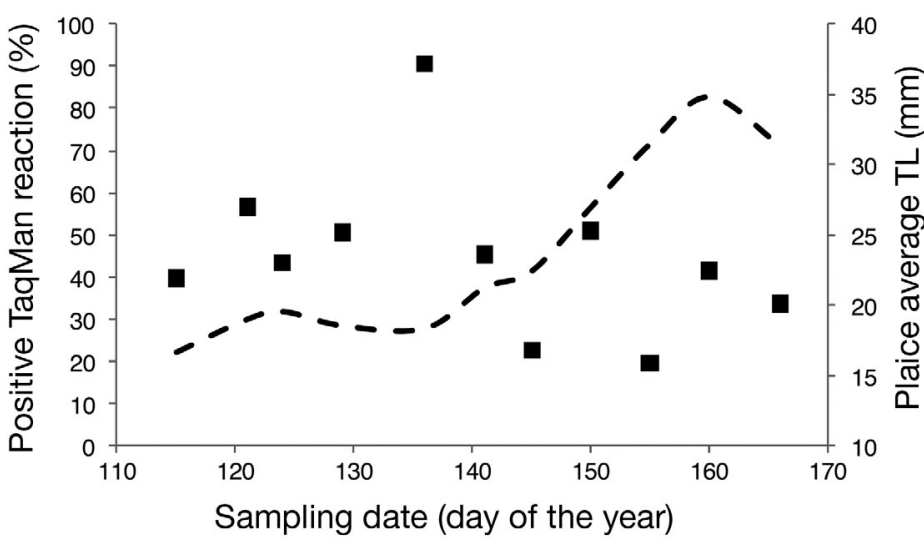

Fig. 3. Crangon crangon predation on Pleuronectes platessa. $\mathbf{0}$ : percentage of stomach contents from shrimp $\geq 7 \mathrm{~mm}$ cephalothorax length (CL) from each sampling date that tested positive for the plaice-specific TaqMan assay. Dashed line: juvenile plaice mean total length (TL) on each sampling date

identity (Gibson \& Robb 1996). TaqMan results suggested that $\sim 6 \%$ of shore crabs may have consumed plaice tissue. Based on visual identification of the fore-gut contents of crabs collected at Tralee between June and August, Ansell et al. (1999) reported a somewhat higher proportion of crabs containing fish remains (55\%). The proportions of roundfish and flatfish in June were approximately equal, but by August flatfish were largely absent from the diet (Ansell et al. 1999). However, because we observed several incidences of crabs feeding on fish in the beam trawl, the estimates in Ansell et al. (1999) are likely to be artefactually high.

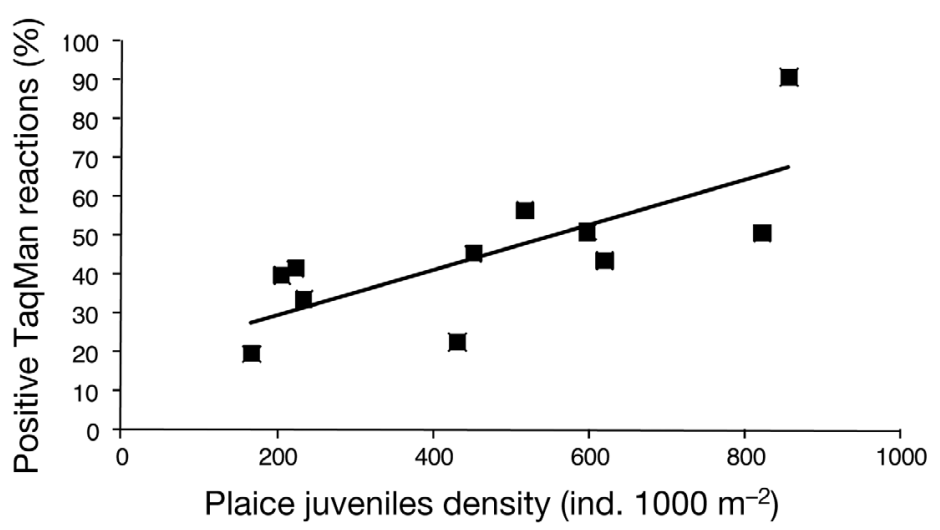

Fig. 4. Crangon crangon predation on Pleuronectes platessa. Relationship between the occurrence of plaice DNA in stomachs of shrimp $\geq 7 \mathrm{~mm}$ cephalothorax length (CL) (\% positive TaqMan reactions) and the density of plaice juveniles (ind. $1000 \mathrm{~m}^{-2}$ ). No correction for catchability of the sampling gear was applied to these estimates. Continuous line represents optimal linear regression model based on Akaike Information Criterion (AIC) fitted to the data $(y=0.0576 x+18.153$; $\mathrm{R}^{2}=0.5456, \mathrm{p}=0.009$ )
Eutrigla gurnardus has been previously reported as a predator of juvenile plaice $(8.3 \%$ occurrence; Ellis \& Gibson 1995) and our molecular results confirm this observation. For Gobiidae, only consumption of dab and flounder has been previously reported (Ellis \& Gibson 1995, Gibson \& Robb 1996), but our results suggest that larger gobies will also take juvenile plaice. Piscine predation on juvenile flatfish has been recognised as an important factor on sandy nursery grounds, especially later in the year (Macer 1967, Edwards \& Steele 1968, Gibson \& Robb 1996). A full evaluation of the range of predators taking post-settlement plaice at Tralee Beach would need to utilise different sampling gears (e.g. beach seine) and sampling would need to continue into the summer and autumn. Because the size of the juvenile flatfish prey will be larger by late summer, the application of molecular probes may have less advantage at this time; evaluating this was beyond the scope of the present study.

\section{Advantages and disadvantages of the molecular approach for dietary studies}

Visually identifying prey remains is time consuming and requires skilled analysts so results are often restricted to broad categories, e.g. roundfish and flatfish (Pihl \& Rosenberg 1984, Pihl 1985, del NorteCampos \& Temming 1994, Ansell et al. 1999, Oh et al. 2001, Chen et al. 2004, Baeta et al. 2006). In the present study, 5 Crangon crangon stomachs contained flatfish remains but only 3 gave positive TaqMan responses, indicating that the shrimp were also eating flatfish other than plaice (probably dab or flounder). Since positive visual identification of small juvenile flatfish requires fin-ray counts (Nichols 1971) and this is usually impossible with partially digested material, the application of molecular techniques represents a significant advance in improving distinction between prey species. The molecular approach was also able to detect plaice DNA even when there were no visually identifiable fish remains in the stomachs, e.g. in shore crabs and in C. crangon of 7 to $8.5 \mathrm{~mm}$ CL.

Experiments using the TaqMan approach have also shown that plaice DNA is detectable in $>90 \%$ of individual shrimp for up to $5 \mathrm{~h}$ post-ingestion (Albaina et al. 2010). This is 


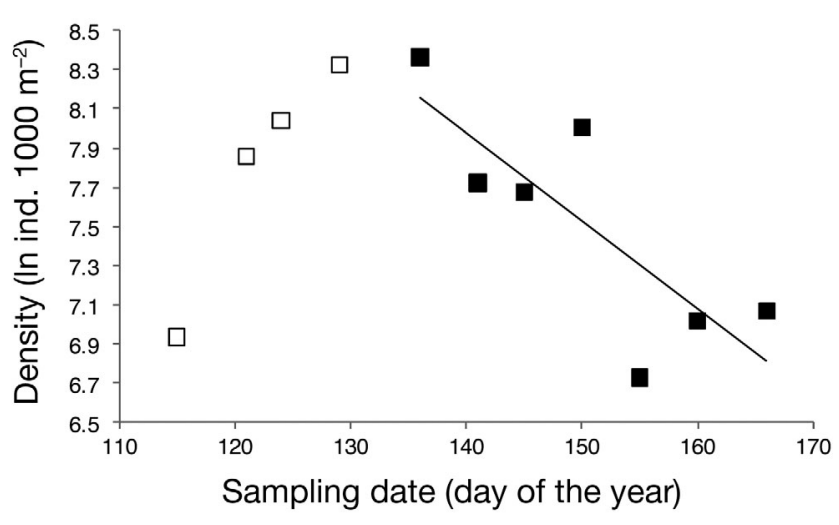

Fig. 5. Pleuronectes platessa. Change in juvenile plaice density over time in spring 2009. Fitted line is the regression of $\log$ plaice abundance versus day of year $(\mathrm{y}=-0.0448 \mathrm{x}+$ 14.251; $\mathrm{R}^{2}=0.6557, \mathrm{p}=0.027$ ) ( $\square$ ) before and ( $\square$ ) after the peak of density. Instantaneous mortality for plaice population is estimated as the linear slope of the decline (ind. $\mathrm{d}^{-1}$ ). Plaice densities were corrected for catchability by beam trawl assuming a fixed catch efficiency of $20 \%$

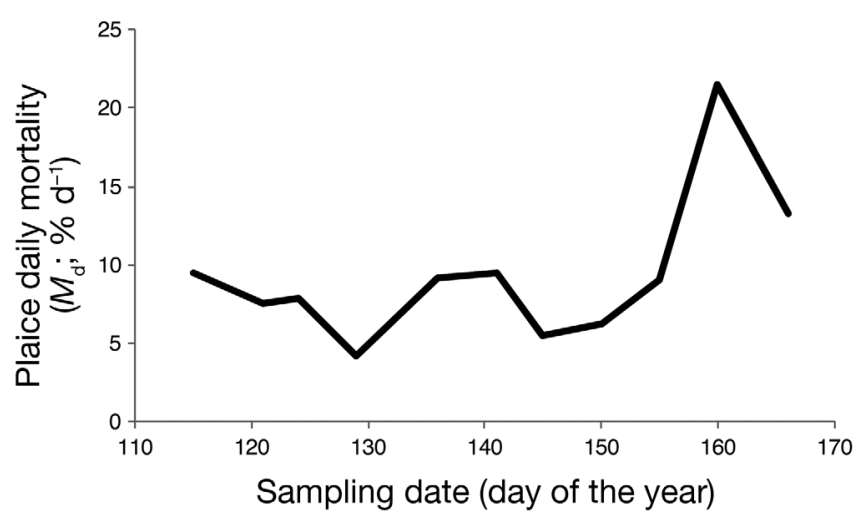

Fig. 6. Pleuronectes platessa. Estimated plaice mortality due to Crangon crangon predation based on TaqMan results. See Eq. (2) in 'Materials and methods' for further information

considerably longer than the time that hard parts have been reported to remain detectable. Based on visual analysis, van der Veer \& Bergman (1987) suggested that the $80 \%$ detection limit for plaice consumed by shrimp was only 2 to $3 \mathrm{~h}$. Longer detection times are clearly advantageous for field studies so that sampling does not need to be so tightly tied to peaks of feeding activity.

A significant disadvantage of present molecular methods for diet studies is that they cannot easily be used to estimate the amounts of prey ingested. Although future developments combining quantitative PCR with fragment-length analysis may have the potential to overcome this limitation (Deagle et al. 2006, Troedsson et al. 2009), we were forced to make several simplifying assumptions in order to convert the binary TaqMan response to estimates of mortality. The main assumption was that each positive TaqMan result corresponded to a single plaice consumed. In experiments, handling times of plaice by shrimp varied from almost instantaneous up to $5 \mathrm{~h}$ depending on the relative sizes of the predator and prey (Gibson et al. 1995). However, consumption rates are the result of a combination of handling, satiation and digestion times and there are rather few reports on consumption rates by individual Crangon crangon. Van der Veer \& Bergman (1987) showed that large shrimp (>60 mm TL) can consume an average of $\sim 0.7$ plaice ( $<25 \mathrm{~mm}$ TL) per predator in a $12 \mathrm{~h}$ period. Consumption rates for both smaller shrimp and larger prey were lower. In experiments conducted by Wennhage (2002) shrimp (32 to $38 \mathrm{~mm}$ TL) could consume up to 4 plaice each over $12 \mathrm{~h}$, but this only occurred at very high prey densities ( $>32$ plaice $\mathrm{m}^{-2}$ ). At prey densities comparable to the present study ( 1 to 5 prey $\mathrm{m}^{-2}$ net avoidance corrected), average consumption dropped to 1 prey or less. However, since these experiments were conducted with 3 predators in each arena, whether each shrimp was consuming partial prey or some shrimp failed to catch any prey at these low densities is unclear. Our assumption of single feeding events does not therefore seem unreasonable, although we cannot eliminate the possibility that several shrimp were feeding on individual prey. The over-estimation of shrimp predation by TaqMan could also be due to partial feeding, i.e. fin nibbling and shrimp abandoning non-lethally wounded prey, or to predators and prey being concentrated at peak feeding times (see 'Discussion: Predation and mortality rates'). Alternative routes by which prey DNA might get into the guts of predators include secondary predation and scavenging (King et al. 2008). While secondary predation of juvenile plaice by shrimp would be highly unlikely, scavenging (including cases of $>1$ shrimp feeding from a single plaice) probably does occur. Macer (1967) also reported that 0-group plaice were found in up to $20 \%$ of stomachs of 1-group plaice so cannibalism may represent an additional source of predation at Tralee that cannot be detected using the present TaqMan approach.

In conclusion, molecular detection of plaice DNA provided a sensitive technique that allowed rapid screening of large numbers of predator stomachs from Tralee Beach. The importance of the brown shrimp as a consumer of recently settled plaice was confirmed and additional potential predators such as shore crab, gurnard and gobies were identified. For 
shrimp, molecular detection rates significantly exceeded the occurrence of visually identifiable remains in shrimp stomachs, suggesting that previous studies may have under-estimated the impact of shrimp on recently settled plaice.

Acknowledgements. The authors thank W. Grail for help with laboratory work. A.A. was supported by a Postdoctoral fellowship from the Education, Universities and Research Department of the Basque Country Government. C.J.F. was supported by NERC Oceans 2025 Program, Theme 4, Work package 4.4 Predators and prey. Probe development and testing was financially supported by Defra (UK Department for Environment, Food and Rural Affairs) under research project MF0432 (Detecting predation on fish eggs and larvae) and by a Small Research Grant award of the Fisheries Society of the British Isles awarded to M.I.T.

\section{LITERATURE CITED}

Albaina A, Fox CJ, Taylor N, Hunter E, Maillard M, Taylor MI (2010) A TaqMan real-time PCR based assay targeting plaice (Pleuronectes platessa L.) DNA to detect predation by the brown shrimp (Crangon crangon L.) and the shore crab (Carcinus maenas L.) - assay development and validation. J Exp Mar Biol Ecol 391:178-189

> Aljanabi SM, Martinez I (1997) Universal and rapid saltextraction of high quality genomic DNA for PCR-based techniques. Nucleic Acids Res 25:4692-4693

> Amara R, Paul C (2003) Seasonal patterns in the fish and epibenthic crustaceans community of an intertidal zone with particular reference to the population dynamics of plaice and brown shrimp. Estuar Coast Shelf Sci 56: 807-818

> Ansell AD, Gibson RN (1993) The effect of sand and light on predation of juvenile plaice (Pleuronectes platessa) by fishes and crustaceans. J Fish Biol 43:837-845

> Ansell AD, Comely CA, Robb L (1999) Distribution, movements and diet of macrocrustaceans on a Scottish sandy beach with particular reference to predation on juvenile fishes. Mar Ecol Prog Ser 176:115-130

> Asahida T, Yamashita Y, Kobayashi T (1997) Identification of consumed stone flounder, Kareius bicoloratus (Basilewsky), from the stomach contents of sand shrimp, Crangon affinis (De Haan) using mitochondrial DNA analysis. J Exp Mar Biol Ecol 217:153-163

> Baeta A, Cabral HN, Marques JC, Pardal MA (2006) Feeding ecology of the green crab, Carcinus maenas (L., 1758) in a temperate estuary, Portugal. Crustaceana 79: 1181-1193

Bailey KM, Brodeur RD, Merati N, Yoklavich MM (1993) Predation on walleye pollock (Theragra chalcogramma) eggs and yolk-sac larvae by pelagic crustacean invertebrates in the western Gulf of Alaska. Fish Oceanogr 2: 30-39

Bannister RCA, Harding D, Lockwood SJ (1974) Larval mortality and subsequent year-class strength in the plaice (Pleuronectes platessa L.). In: Blaxter JHS (ed) The early life history of fish. Springer, Berlin, p 21-37

> Barnett A, Redd KS, Frusher SD, Stevens JD, Semmens JM (2010) Non-lethal method to obtain stomach samples from a large marine predator and the use of DNA analy- sis to improve dietary information. J Exp Mar Biol Ecol 393:188-192

Beverton RJH, Iles TC (1992) Mortality rates of 0-group plaice (Pleuronectes platessa L.), dab (Limanda limanda L.) and turbot (Scophthalmus maximus L.) in European waters: III. Density dependence of mortality rates of 0 -group plaice and some demographic implications. Neth J Sea Res 29:61-79

- Braley M, Goldsworthy SD, Page B, Steer M, Austin JJ (2010) Assessing morphological and DNA-based diet analysis techniques in a generalist predator, the arrow squid Nototodarus gouldi. Mol Ecol Resour 10:466-474

> Burrows MT, Gibson RN, Robb L, Comely CA (1994) Temporal patterns of movement in juvenile flatfishes and their predators: underwater television observations. J Exp Mar Biol Ecol 177:251-268

> Burrows MT, Gontarek SJ, Nash RDM, Gibson RN (2001) Shrimp predation on 0-group plaice: contrasts between field data and predictions of an individual-based model. J Sea Res 45:243-254

Chen RB, Watanabe S, Yokota M (2004) Feeding habits of an exotic species, the Mediterranean green crab Carcinus aestuarii, in Tokyo Bay. Fish Sci 70:430-435

Deagle BE, Eveson JP, Jarman SN (2006) Quantification of damage in DNA recovered from highly degraded samples - a case study on DNA in faeces. Front Zool 3:11

> Deagle BE, Kirkwood R, Jarman SN (2009) Analysis of Australian fur seal diet by pyrosequencing prey DNA in faeces. Mol Ecol 18:2022-2038

del Norte-Campos AGC, Temming A (1994) Daily activity, feeding and rations in gobies and brown shrimp in the northern Wadden Sea. Mar Ecol Prog Ser 115:41-53

Edwards RRC, Steele JH (1968) The ecology of 0-group plaice and common dabs at Lochewe. I. Population and food. J Exp Mar Biol Ecol 2:215-238

> Ellis T, Gibson RN (1995) Size-selective predation of 0 -group flatfishes on a Scottish coastal nursery ground. Mar Ecol Prog Ser 127:27-37

Ellis T, Nash RDM (1997) Predation by sprat and herring on pelagic fish eggs in a plaice spawning area in the Irish Sea. J Fish Biol 50:1195-1202

Fox CJ, McCloghrie P, Young EF, Nash RDM (2006) The importance of individual behaviour for successful settlement of juvenile plaice (Pleuronectes platessa L.): a modelling and field study in the eastern Irish Sea. Fish Oceanogr 15:301-313

Freitas V, Campos J, Skreslet S, van der Veer HW (2010) Habitat quality of a subarctic nursery ground for 0-group plaice (Pleuronectes platessa L.). J Sea Res 64:26-33

Gibson RN, Robb L (1996) Piscine predation on juvenile fishes on a Scottish sandy beach. J Fish Biol 49:120-138

Gibson RN, Ansell AD, Robb L (1993) Seasonal and annual variations in abundance and species composition of fish and macrocrustacean communities on a Scottish sandy beach. Mar Ecol Prog Ser 98:89-105

> Gibson RN, Yin MC, Robb L (1995) The behavioural basis of predator-prey size relationships between shrimp (Crangon crangon) and juvenile plaice (Pleuronectes platessa). J Mar Biol Assoc UK 75:337-349

> Gibson RN, Robb L, Burrows MT, Ansell AD (1996) Tidal, diel and longer term changes in the distribution of fishes on a Scottish sandy beach. Mar Ecol Prog Ser 130:1-17

Gibson RN, Pihl L, Burrows MT, Modin J, Wennhage H, Nickell LA (1998) Diel movements of juvenile plaice Pleuronectes platessa in relation to predators, competi- 
tors, food availability and abiotic factors on a microtidal nursery ground. Mar Ecol Prog Ser 165:145-159

Gibson RN, Robb L, Wennhage H, Burrows MT (2002) Ontogenetic changes in depth distribution of juvenile flatfishes in relation to predation risk and temperature on a shallowwater nursery ground. Mar Ecol Prog Ser 229:233-244

Granadeiro JP, Silva MA (2000) The use of otoliths and vertebrae in the identification and size-estimation of fish in predator-prey studies. Cybium 24:383-393

- Hamer KC, Humphreys EM, Garthe S, Hennicke J and others (2007) Annual variation in diets, feeding locations and foraging behaviour of gannets in the North Sea: flexibility, consistency and constraint. Mar Ecol Prog Ser 338: 295-305

> Iles TC, Beverton RJH (1991) Mortality rates of 0-group plaice (Pleuronectes platessa L.), dab (Limanda limanda L.) and turbot (Scophthalmus maximus L.) in European waters: I. Statistical analysis of the data and estimation of parameters. Neth J Sea Res 27:217-235

> Iles TC, Beverton RJH (2000) The concentration hypothesis: the statistical evidence. ICES J Mar Sci 57:216-227

King RA, Read DS, Traugott M, Symondson WOC (2008) Molecular analysis of predation: a review of best practice for DNA-based approaches. Mol Ecol 17:947-963

Kuipers BR, Currin BM, Miller JM, van der Veer HW, de Witte JIJ (1992) Small trawls in juvenile flatfish research: their development and efficiency. Neth J Sea Res 29: 109-117

Labansen AL, Lydersen C, Haug T, Kovacs KM (2007) Spring diet of ringed seals (Phoca hispida) from northwestern Spitsbergen, Norway. ICES J Mar Sci 64:1246-1256

Leopold MF, van Damme CJG, van der Veer HW (1998) Diet of cormorants and the impact of cormorant predation on juvenile flatfish in the Dutch Wadden Sea. J Sea Res 40: 93-107

- Lockwood SJ, Daly C de B (1975) Further observations on the effects of preservation in $4 \%$ neutral formalin on the length and weight of 0-group flatfish. J Cons Int Explor Mer 36:170-175

> Macer CT (1967) The food web in Red Wharf Bay (North Wales) with particular reference to young plaice (Pleuronectes platessa). Helgol Wiss Meeresunters 15: 560-573

Marshall HD, Hart KA, Yaskowiak ES, Stenson GB, McKinnon D, Perry EA (2010) Molecular identification of prey in the stomach contents of harp seals (Pagophilus groenlandicus) using species-specific oligonucleotides. Mol Ecol Resour 10:181-189

Nash RDM, Geffen AJ (2000) The influence of nursery ground processes in the determination of year-class strength in juvenile plaice Pleuronectes platessa L. in Port Erin Bay, Irish Sea. J Sea Res 44:101-110

> Nash RDM, Geffen AJ, Burrows MT, Gibson RN (2007) Dynamics of shallow-water juvenile flatfish nursery grounds: application of the self-thinning rule. Mar Ecol Prog Ser 344:231-244

Naviaux RK, Good B, McPherson JD, Steffen DL, Markusic D, Ransom B, Corbeil J (2005) Sand DNA - a genetic library of life at the water's edge. Mar Ecol Prog Ser 301: 9-22

> Nejstgaard JC, Frischer ME, Raule CL, Gruebel RC, Kohlberg KE, Verity PG (2003) Molecular detection of algal prey in copepod guts and fecal pellets. Limnol Oceanogr Methods 1:29-38

Nichols JH (1971) Pleuronectidae. Fiches d'identification des oeufs et larves de poissons, Fiches 4-6. Conseil International pour l'Exploration de la Mer, Copenhagen

Oh CW, Hartnoll RG, Nash RDM (2001) Feeding ecology of the common shrimp Crangon crangon in Port Erin Bay, Isle of Man, Irish Sea. Mar Ecol Prog Ser 214:211-223

Pihl L (1985) Food selection and consumption of mobile epibenthic fauna in shallow marine areas. Mar Ecol Prog Ser 22:169-179

> Pihl L, Rosenberg R (1984) Food selection and consumption of the shrimp Crangon crangon in some shallow marine areas in western Sweden. Mar Ecol Prog Ser 15: $159-168$

Rogers SI, Lockwood SJ (1989) Observations on the capture efficiency of a two-metre beam trawl for juvenile flatfish. Neth J Sea Res 23:347-352

Rosel PE, Kocher TD (2002) DNA-based identification of larval cod in stomach contents of predatory fishes. J Exp Mar Biol Ecol 267:75-88

Saitoh K, Takagaki M, Yamashita Y (2003) Detection of Japanese flounder-specific DNA from gut contents of potential predators in the field. Fish Sci 69:473-477

Smith PJ, McVeagh SM, Allain V, Sanchez C (2005) DNA identification of gut contents of large pelagic fishes. J Fish Biol 67:1178-1183

Symondson WOC (2002) Molecular identification of prey in predator diets. Mol Ecol 11:627-641

> Taylor DL (2004) Immunological detection of winter flounder (Pseudopleuronectes americanus) eggs and juveniles in the stomach contents of crustacean predators. J Exp Mar Biol Ecol 301:55-73

Taylor DL (2005a) Predation on post-settlement winter flounder Pseudopleuronectes americanus by sand shrimp Crangon septemspinosa in NW Atlantic estuaries. Mar Ecol Prog Ser 289:245-262

> Taylor DL (2005b) Predatory impact of the green crab (Carcinus maenas Linnaeus) on post-settlement winter flounder (Pseudopleuronectes americanus Walbaum) as revealed by immunological dietary analysis. J Exp Mar Biol Ecol 324:112-126

Troedsson C, Frischer ME, Nejstgaard JC, Thompson EM (2007) Molecular quantification of differential ingestion and particle trapping rates by the appendicularian Oikopleura dioica as a function of prey size and shape. Limnol Oceanogr 52:416-427

Troedsson C, Simonelli P, Nägele V, Nejstgaard JC, Frischer ME (2009) Quantification of copepod gut content by differential length amplification quantitative PCR (dlaqPCR). Mar Biol 156:253-259

van der Veer HW, Bergman MJN (1987) Predation by crustaceans on a newly settled 0-group plaice Pleuronectes platessa population in the western Wadden Sea. Mar Ecol Prog Ser 35:203-215

> van der Veer HW, Bolle LJ, Geffen AJ, Witte JIJ (2009) Variability in transport of fish eggs and larvae. IV. Interannual variability in larval stage duration of immigrating plaice in the Dutch Wadden Sea. Mar Ecol Prog Ser 390: 213-223

> Wennhage H (2002) Vulnerability of newly settled plaice (Pleuronectes platessa L.) to predation: effects of habitat structure and predator functional response. J Exp Mar Biol Ecol 269:129-145

Wennhage H, Gibson RN, Robb L (1997) The use of drop traps to estimate the efficiency of two bean trawls commonly used for sampling juvenile flatfishes. J Fish Biol 51:441-445 


\section{Appendix}

Table A1. Taxa caught at Tralee in spring 2009. Mean and maximum densities (ind. $1000 \mathrm{~m}^{-2}$ ) for the 11 sampling dates along with the relative density (\%) pooling all surveys together. No correction for catchability of the sampling gear was applied

\begin{tabular}{|lrrr|}
\hline Species & \multicolumn{2}{c}{ Density (ind. $1000 \mathrm{~m}^{-2}$ ) } & $\begin{array}{c}\text { Relative } \\
\text { density }(\%)\end{array}$ \\
\hline Mean & 567.22 & 2027.47 & 39.438 \\
Pleuronectes platessa & 483.88 & 862.97 & 36.478 \\
Gobiidae & 167.71 & 1146.07 & 10.383 \\
Ammodytes spp. & 101.44 & 496.88 & 6.197 \\
Carcinus maenas & 37.60 & 88.00 & 2.740 \\
Limanda limanda & 28.42 & 110.26 & 1.928 \\
Platichthys flesus & 21.02 & 142.32 & 1.281 \\
Solea solea & 9.42 & 46.65 & 0.702 \\
Clupeidae & 4.07 & 42.68 & 0.303 \\
Eutrigla gurnardus & 1.99 & 10.26 & 0.124 \\
Syngnathus rostellatus & 1.19 & 3.89 & 0.083 \\
Pleuronectidae unknown & 0.73 & 2.56 & 0.055 \\
Myoxocephalus scorpius & 0.60 & 2.67 & 0.041 \\
Liocarcinus holsatus & 0.61 & 2.67 & 0.041 \\
Cyclopterus lumpus & 0.55 & 2.03 & 0.041 \\
Gadidae & 0.35 & 3.89 & 0.028 \\
Agonus cataphractus & 0.40 & 2.50 & 0.028 \\
Spinachia spinachia & 0.36 & 2.01 & 0.028 \\
Pollachius virens & 0.35 & 3.89 & 0.028 \\
Pholis gunnellus & 0.23 & 2.50 & 0.014 \\
Gobiesocidae & 0.18 & 2.03 & 0.014 \\
Clupea harengus & 0.17 & 1.90 & 0.014 \\
\hline
\end{tabular}

Table A2. Crangon crangon. Effect of shrimp sex and female gonad maturation on the (A) descriptive criteria for shrimp $\geq 7 \mathrm{~mm}$ cephalothorax length (CL) collected during sampling and (B) occurrence of different prey items in the stomachs of shrimps determined though visual identification. GS: Gonad Stage (see 'Materials and methods'). All the sampling dates were pooled

\begin{tabular}{|c|c|c|c|c|c|c|}
\hline & Male & Female (all) & Female GS1 & Female GS2 & Female GS3 & Female GS4 \\
\hline \multicolumn{7}{|c|}{ (A) Descriptive criteria } \\
\hline No. of shrimp & 505 & 632 & 351 & 22 & 55 & 203 \\
\hline Size (mm CL) & 7.51 & 9.63 & 8.82 & 10.48 & 10.53 & 10.72 \\
\hline$\%$ fullness index 3 & 46.93 & 43.42 & 52.42 & 40.91 & 23.64 & 33.50 \\
\hline \multicolumn{7}{|c|}{ (B) Prey items in the shrimp stomachs (\% occurrence) } \\
\hline Fish total & 0.99 & 2.37 & 0.85 & 13.64 & 0 & 4.43 \\
\hline Flatfish & 0.20 & 0.63 & 0.28 & 4.55 & 0 & 0.99 \\
\hline Crustacean total & 26.34 & 29.91 & 32.19 & 27.27 & 18.18 & 29.56 \\
\hline Mysid & 11.29 & 14.56 & 14.53 & 18.18 & 7.27 & 16.26 \\
\hline
\end{tabular}


Table A3. Ammodytes spp., Eutrigla gurnardus, Gobiidae. (A) Descriptive criteria of fish collected during sampling. (B) Diet of 3 fish taxa identified from visual inspection of stomach contents. Prey is reported as percentage of occurrence. Results are limited to $1 \mathrm{yr}+$ fish individuals. TL: total length

\begin{tabular}{|lccc|}
\hline & Gobiidae & $\begin{array}{c}\text { Ammodytes } \\
\text { spp. }\end{array}$ & $\begin{array}{c}\text { Eutrigla } \\
\text { gurnardus }\end{array}$ \\
\hline (A) Descriptive criteria & & & \\
No. of fish & 57 & 18 & 5 \\
Size (mm TL) & $56.75 \pm 8.26$ & $105.53 \pm 26.05$ & $88.1 \pm 23.13$ \\
\% fullness index 3 & 70.18 & 61.11 & 100.00 \\
& & & \\
(B) Prey items in the fish stomachs (\% occurrence) & \\
Unidentified plankton & 89.47 & 83.33 & 0.00 \\
Fish total & 8.77 & 0.00 & 20.00 \\
Flatfish & 1.75 & 0.00 & 20.00 \\
Roundfish & 8.77 & 0.00 & 0.00 \\
Unknown fish & 1.75 & 0.00 & 20.00 \\
Crustacean total & 28.07 & 11.11 & 100.00 \\
Mysid & 8.77 & 0.00 & 20.00 \\
Amphipod & 12.28 & 0.00 & 80.00 \\
Isopod & 0.00 & 0.00 & 0.00 \\
Crangon crangon (juvenile) & 7.02 & 5.56 & 80.00 \\
Unknown crustacean & 7.02 & 5.56 & 0.00 \\
\hline
\end{tabular}

Editorial responsibility: Nicholas Tolimieri, Seattle, Washington, USA
Submitted: June 23, 2011; Accepted: October 3, 2011 Proofs received from author(s): December 14, 2011 